\title{
Effects of D-Glutamate on Mycelial Growth and Glutamate Dehydrogenase Enzymes of Coprinus lagopus
}

\author{
By A. AL-GHARAWI AND D. MOORE \\ Department of Zoology and Department of Botany, \\ The University, Manchester MI3 9PL \\ (Received 3I May 1974; revised 22 July 1974)
}

\begin{abstract}
SUMMARY
D-Glutamate inhibited hyphal extension, the degree of inhibition depending on the identity of the glutamate dehydrogenase (GDH) enzyme present in the mycelium. Mycelia were most sensitive to inhibition on media which promoted formation of the NAD-linked GDH. The activity of this enzyme was inhibited by D-glutamate in experiments with cell-free extracts, the inhibitions being noncompetitive or mixed. Similarly the activity of the NADP-linked enzyme $\left(\mathrm{GDH}_{\text {NADP }}\right)$ was inhibited in its utilization of ammonium ions (in the amination reaction) and L-glutamate (in the deamination reaction). In contrast, 2-oxoglutarate was a co-operative substrate for $\mathrm{GDH}_{\mathrm{NADP}}$ in the amination reaction and Dglutamate acted as an allosteric activator. D-Glutamate was also able to derepress the synthesis of $\mathrm{GDH}_{\mathrm{NADP}}$; the NAD-linked enzyme was hardly affected.
\end{abstract}

\section{INTRODUCTION}

The Basidiomycete fungus Coprinus lagopus produces two L-glutamate dehydrogenase (GDH) enzymes, the relative activities of which in vegetative mycelia depend on the carbon and nitrogen sources present in the medium (Fawole \& Casselton, 1972). On media containing acetate as sole carbon source the NAD-linked enzyme $\left(\mathrm{GDH}_{\mathrm{NAD}}\right)$ is derepressed while activity of the NADP-linked species $\left(\mathrm{GDH}_{\mathrm{NADP}}\right)$ is repressed. The $\mathrm{GDH}_{\mathrm{NAD}}$, however, is subject to catabolite repression, and on media containing high concentrations of glucose the specific activity of $\mathrm{GDH}_{\mathrm{NAD}}$ is greatly reduced while that of $\mathrm{GDH}_{\mathrm{NADP}}$ is increased. Urea as sole nitrogen source influences the synthesis of GDH enzymes, repressing $\mathrm{GDH}_{\mathrm{NADP}}$ and derepressing $\mathrm{GDH}_{\mathrm{NAD}}$ whatever the carbon source (Fawole \& Casselton, 1972; Stewart \& Moore, 1974).

These two enzymes are of considerable importance in general metabolism. The reactions they catalyse (reductive amination of 2-oxoglutarate to L-glutamate and the reverse reaction, oxidative deamination of L-glutamate) provide a major route of ammonia assimilation, an important conjunction between catabolism and protein synthesis, and may also be important in determining the general availability of oxidized and reduced forms of the NAD and NADP coenzymes (Frieden, I963). The enzymes have also been implicated in a number of developmental processes. In Neurospora, conidial germination is accompanied by a rapid increase in $\mathrm{GDH}_{\mathrm{NADP}}$ activity; this activity subsequently declines and $\mathrm{GDH}_{\mathrm{NAD}}$ activity increases as the conidia age (Sanwal \& Lata, I962; Tuveson, West \& Barratt, 1967; Stine, 1968). In Schizophyllum commune, vegetative hyphal growth is characterized by a lower $\mathrm{GDH}_{\mathrm{NADP}}$ than $\mathrm{GDH}_{\mathrm{NAD}}$ activity, yet the activity of $\mathrm{GDH}_{\mathrm{NADP}}$ increased in germinating basidiospores irrespective of the mycelium used (Dennen \& Niederpruem, 1965). In Coprinus lagopus also, $\mathrm{GDH}_{\mathrm{NADP}}$ activity is low in vegetative mycelia growing on normal 
media, yet it is greatly increased in the pilei (but not stipes) of sporophores developing on those same mycelia (Stewart \& Moore, 1974).

The roles that these enzymes play in morphogenesis are not known. Specific inhibitors offer a means of manipulating the enzyme activities in ways that might reveal these roles, either by the direct application of the inhibitor as an unnatural component of the morphogenetic system or by the study of the same morphogenetic process in mutants selected for resistance to inhibition. D-Amino acids generally inhibit the activity of enzymes whose normal substrates are their L-isomers. D-Glutamate inhibits the activity of L-glutamate decarboxylase in Escherichia coli (Roberts, I953) and in beef liver GDH (Olson \& Anfinsen, I953), and inhibits both growth and $\mathrm{GDH}_{\mathrm{NADP}}$ activity in Neurospora crassa (Arkin \& Grossowicz, 1970). The latter inhibition was reversed by addition of L-glutamate or L-glutamine and it was concluded that growth inhibition resulted directly from a specific inhibition of GDH by D-glutamate.

We have investigated the effect of D-glutamate on Coprinus lagopus. Its influence on both hyphal growth and the kinetics of GDH activity have been studied, to provide an adequate foundation for the use of this agent in morphogenetic studies of the sort indicated above.

\section{METHODS}

Organism. The Basidiomycete Coprinus lagopus (sensu Lewis) $[=C$. cinereus (Schaeff. ex Fr.) S. F. Gray] was used throughout this work. A monokaryotic wild-type strain, stock number $\mathrm{BC} 9 / 6,6$ (mating type $\mathrm{A}_{6} \mathrm{~B}_{6}$ ), was used in experiments involving living mycelia. Since both GDH enzymes occur at high specific activities in sporophore pilei this tissue was used as a source of enzymes for the in vitro kinetic experiments. The sporophores were produced by growing a dikaryon made from $\mathrm{BC} 9 / 6,6$ and another compatible wild-type monokaryon (strain $\mathrm{HI}$, mating type $\mathrm{A}_{5} \mathrm{~B}_{5}$ ) on sterile horse dung contained in crystallizing dishes.

Media. A completely defined basal medium (SNC) was used for experiments in which carbon and/or nitrogen sources were varied. SNC consisted of Io mM- $\mathrm{Na}_{2} \mathrm{HPO}_{4}$, $10 \mathrm{mM}$ $\mathrm{KH}_{2} \mathrm{PO}_{4}, 2 \mathrm{~mm}-\mathrm{Na}_{2} \mathrm{SO}_{4}, 0.5 \mathrm{~mm}-\mathrm{MgSO}_{4}$, and $3.0 \mu \mathrm{M}$-thiamin hydrochloride. The medium was solidified, if required, with $\mathrm{I} \cdot 5 \%$ (w/v) Difco Bacto-agar and sterilized by autoclaving at $\mathrm{I} 2 \mathrm{I}{ }^{\circ} \mathrm{C}$ for $\mathrm{I} 5 \mathrm{~min}$. The $\mathrm{pH}$ of the medium was 6.8 after autoclaving. Previously sterilized stock solutions of carbon and nitrogen sources were added as required to the basal medium after autoclaving.

Colony growth rates. The gross physiological effects of D-glutamate were determined by assessing colony growth rates using the techniques detailed by Moore \& Stewart (1972). All cultures were incubated at $37^{\circ} \mathrm{C}$.

Liquid medium cultures. Mycelia were grown in $100 \mathrm{ml}$ quantities of liquid medium contained in $500 \mathrm{ml}$ conical flasks. The flasks were inoculated with asexual spores (oidia) of strain $\mathrm{BC} 9 / 6,6$ and incubated at $37^{\circ} \mathrm{C}$ on an orbital shaker operating at $120 \mathrm{rev} / \mathrm{min}$. After 3 to 4 days' growth the mycelia were harvested by filtration through Whatman GF/A filter discs and cell-free extracts prepared as described below.

Cell-free extracts. Sporophore cap tissue was harvested at a late stage of development (at, or just before, the discharge of mature spores) and stored at $-30{ }^{\circ} \mathrm{C}$ until required. Storage was limited to less than 7 days when $\mathrm{GDH}_{\mathrm{NAD}}$ was to be assayed and less than 3 days for $\mathrm{GDH}_{\text {NADP }}$ experiments. Mycelia harvested after growth in liquid media were treated similarly. Quantities of tissue were extracted by grinding with acid-washed sand in a buffer appropriate to the intended enzyme assay (see below). Crude extracts were obtained by 


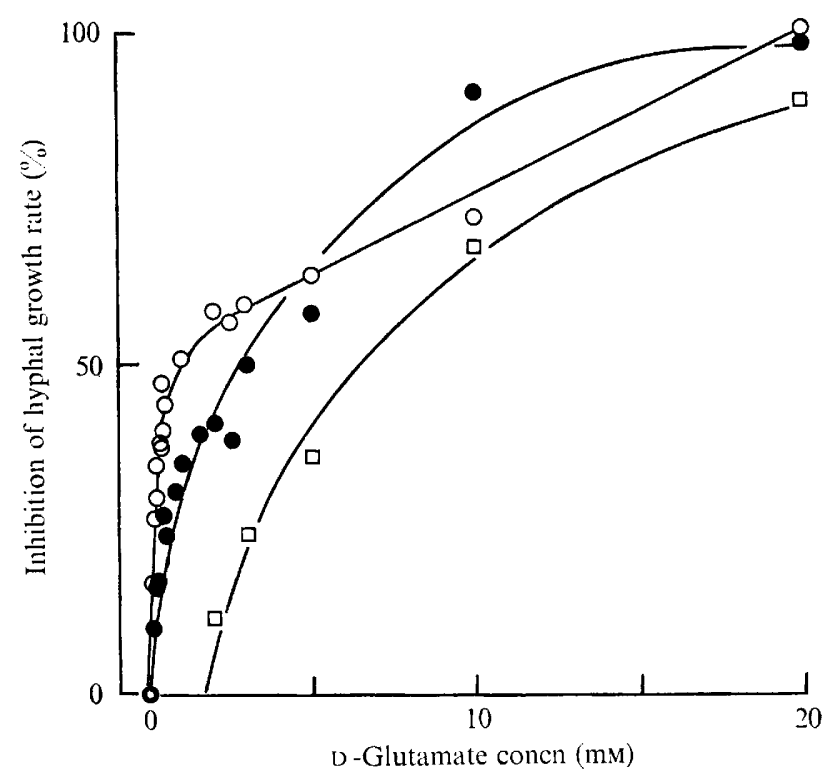

Fig. I. Inhibition of hyphal extension growth by D-glutamate in basal medium with the following additions: $O, 25 \mathrm{~mm}$-sodium acetate $+25 \mathrm{~mm}$-urea; $\square, \quad$ I $00 \mathrm{~mm}$-glucose $+75 \mathrm{~mm}$-ammonium tartrate;, 25 mM-glucose +25 mM-ammonium tartrate.

filtration through Whatman GF/A filters followed by desalting on a small column of Sephadex G-25 equilibrated with extraction buffer. The preparations were kept at temperatures below $5{ }^{\circ} \mathrm{C}$ throughout the extraction procedures.

Enzyme assays. GDH activity was determined at $30{ }^{\circ} \mathrm{C}$ in a Pye Unicam SP I80oB recording spectrophotometer. The assay medium for the amination reaction was made up in 0.I M-sodium phosphate buffer at $\mathrm{pH} 7.5$ for $\mathrm{GDH}_{\mathrm{NADP}}$ and at $\mathrm{pH} 8.0$ for $\mathrm{GDH}_{\mathrm{NAD}}$. For the deamination reaction a glycine/ $\mathrm{NaOH}$ buffer was used at $0.05 \mathrm{M}$ and $\mathrm{pH} 9.0\left(\mathrm{GDH}_{\mathrm{NADP}}\right)$ or 9.6 $\left(\mathrm{GDH}_{\mathrm{NAD}}\right)$. Concentrations of other components of the four standard assay mixtures were: $\mathrm{GDH}_{\mathrm{NAD}}$ aminating - $9.6 \mathrm{~mm}-2$-oxoglutarate, $40.0 \mathrm{mM}-\mathrm{NH}_{4} \mathrm{Cl}$ and $0.14 \mathrm{I} \mathrm{mM-NADH}$; $\mathrm{GDH}_{\mathrm{NAD}}$ deaminating-80.0 mM-sodium glutamate and $0.207 \mathrm{mM}^{-N A D}{ }^{+} ; \mathrm{GDH}_{\mathrm{NADP}}$

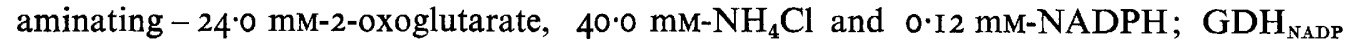
deaminating - I20.0 mM-sodium glutamate and $0.187 \mathrm{~mm}-\mathrm{NADP}{ }^{+}$. The final volume of each reaction mixture was $2.5 \mathrm{ml}$ and $0.25 \mathrm{ml}$ of extract was used. Reactions were initiated by addition of extract and change in $E_{340}$ was followed. Rates were linear over the first 60 to $\mathrm{I} 80 \mathrm{~s}$ and were directly proportional to the volume of extract added.

Protein was determined after precipitation with $10 \%(\mathrm{w} / \mathrm{v})$ trichloroacetic acid by the method of Lowry, Rosebrough, Farr \& Randall (I95I) using bovine serum albumin as a standard.

Specific activities are expressed as $\mu \mathrm{mol}$ coenzyme oxidized or reduced $/ \mathrm{min} / \mathrm{mg}$ protein under the standard assay conditions.

Reagents. Biochemicals were purchased from Sigma, and all other chemicals, of analytical grade where possible, from $\mathrm{BDH}$. 
Table $\mathrm{I}$. Effect of $\mathrm{L}-$ glutamate and $\mathrm{L}$-glutamine on growth rate inhibitions caused by D-glutamate

Extension growth rates of the wild-type monokaryon BC9/6,6 were determined on the indicated media and percentage inhibitions calculated by reference to the growth rate on the basal medium alone.

Basal medium

25 mM-Acetate +25 mm-urea

$100 \mathrm{~mm}$-Glucose $+75 \mathrm{~mm}$-ammonium tartrate
Concentration (mM) of:

$\begin{array}{cccc}\text { D-Glutamate } & \text { L-Glutamate } & \text { L-Glutamine } & \begin{array}{c}\text { Inhibition } \\ (\%)\end{array} \\ 3.0 & - & - & 69.1 \\ 3.0 & 0.3 & - & 57.3 \\ 3.0 & 3.0 & - & 32.4 \\ 3.0 & 30.0 & - & 7.4 \\ 3.0 & - & 0.3 & 67.0 \\ 3.0 & - & 3.0 & 58.6 \\ 5.0 & - & - & 24.3 \\ 5.0 & 5.0 & - & 16.5 \\ 5.0 & 50.0 & - & 1.7 \\ 5.0 & - & 5.0 & 37.8 \\ 10.0 & - & - & 70.0 \\ 10.0 & 10.0 & - & 65.8 \\ 10.0 & 100.0 & - & 50.1 \\ 10.0 & - & 10.0 & 70.2\end{array}$

RESULTS

Effects of D-glutamate on colonial growth

The relative specific activities of the NAD- and NADP-linked GDH enzymes of Coprinus vegetative mycelia are profoundly influenced by the carbon and nitrogen sources contained in the medium (Fawole \& Casselton, 1972). On a medium containing 25 mM-sodium acetate and $25 \mathrm{mM}$-urea the specific activity of $\mathrm{GDH}_{\mathrm{NAD}}$ is characteristically some 60 times greater than that of $\mathrm{GDH}_{\mathrm{NADP}}$. In contrast, growth on $100 \mathrm{mM}$-glucose and $75 \mathrm{mM}$-ammonium tartrate increases the specific activity of $\mathrm{GDH}_{\mathrm{XADP}}$ so that it at least equals and usually slightly exceeds the reduced specific activity of $\mathrm{GDH}_{\text {NAD }}$ (see Table 4 below). These two media were used in experiments in which extension growth rates were determined in the presence of different concentrations of D-glutamate. The object was to investigate the effects of the inhibitor on mycelia which differed as much as possible in the pattern of their GDH enzymes. A considerable difference in sensitivity was observed (Fig. I). Such mediumdependent sensitivity differentials have been observed before in Coprinus (Moore, I968; Moore \& Stewart, 1972) and been related to the carbon sources present in the media. That the differences observed here are not due simply to one medium containing acetate while the other contains glucose is apparent from Fig. I, which shows the pattern of growth rate inhibitions observed using a basal medium containing $25 \mathrm{mM}$-glucose and $25 \mathrm{~mm}$ ammonium tartrate. Although quite adequate to support vigorous growth, these concentrations of glucose and ammonium salt are too low to affect the specific activity of $\mathrm{GDH}_{\text {NADF }}$ (which remains at about $0.05 \mu \mathrm{mol}$ coenzyme oxidized $/ \mathrm{min} / \mathrm{mg}$ protein) and only slightly reduce the level of $\mathrm{GDH}_{\mathrm{XAD}}$ activity (to about $2.0 \mu \mathrm{mol}$ ) so that there remains an approximately 40 -fold excess of $\mathrm{GDH}_{\mathrm{NAD}}$ over $\mathrm{GDH}_{\mathrm{NADP}}$. The pattern of inhibition observed (Fig. I) more closely resembles that seen on the acetate-urea medium than on the glucoseammonium medium. Thus growth inhibition by D-glutamate must depend more on the nature and activity of the GDH enzyme present in the mycelium than on the identities of 

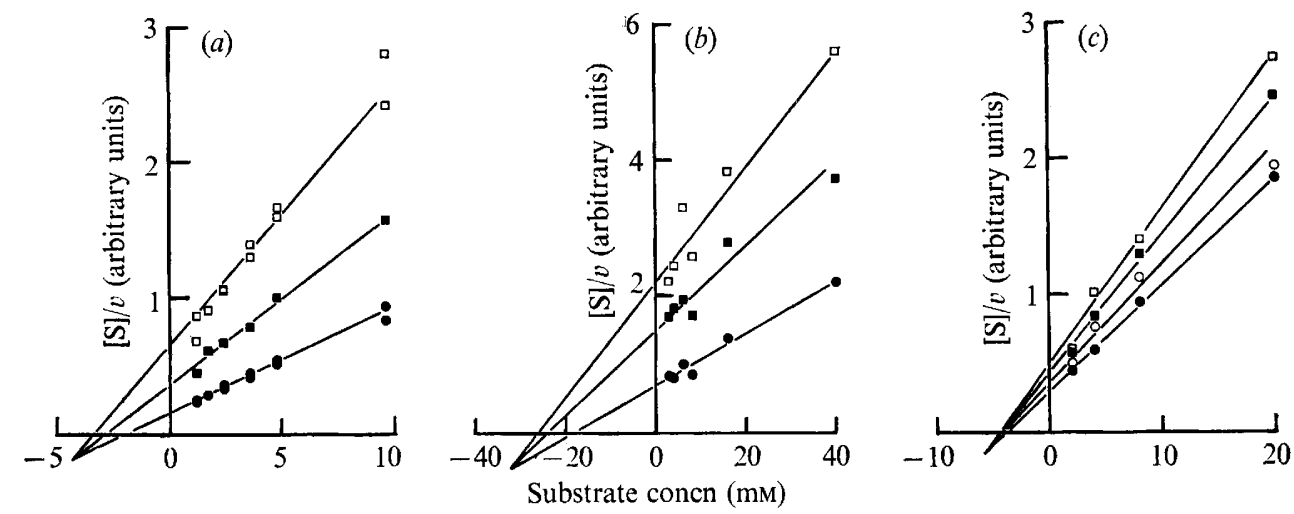

Fig. 2. Effect of D-glutamate on $\mathrm{GDH}_{\mathrm{NAD}}$ activity in the presence of varying concentrations of (a) 2-oxoglutarate, $(b)$ ammonium chloride, or $(c)$ L-glutamate. [S], substrate concentration; $v$, the corresponding reaction velocity. D-Glutamate concentrations were: 0 , none; $O, 2 \mathrm{~mm} ; \mathbf{\square}, 7 \mathrm{~mm}$; ㅁ, 15 mm.
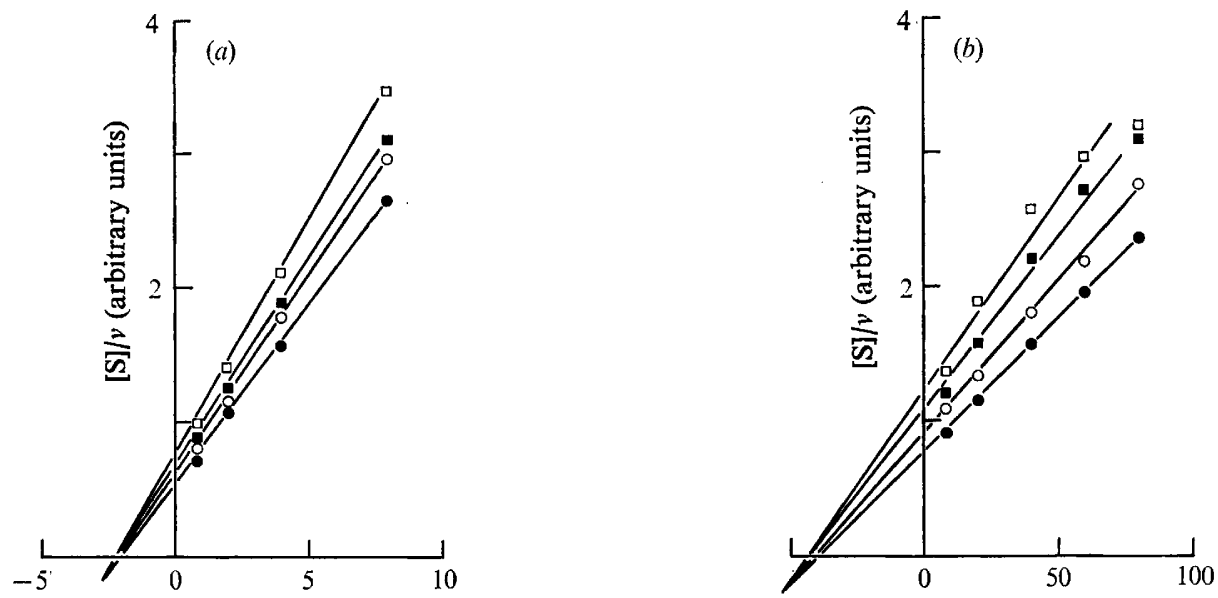

Substrate concn (mM)

Fig. 3. Effect of D-glutamate on $\mathrm{GDH}_{\mathrm{NADP}}$ activity in the presence of varying concentrations of (a) ammonium chloride or (b) L-glutamate. For symbols see Fig. 2.

Table 2. Comparison of the kinetic constants of the two GDH enzymes of Coprinus

Entries in the Table are the means and standard errors of 2 to 6 determinations. Because of the mixed nature of most of the inhibitions the values quoted for $K_{i}$ can only be considered as approxjmations.

$\begin{array}{lcc} & \begin{array}{c}\mathrm{GDH}_{\mathrm{NAD}} \\ (\mathrm{mM})\end{array} & \begin{array}{c}\mathrm{GDH}_{\mathrm{NADP}} \\ (\mathrm{mM})\end{array} \\ K_{m} & & \\ \quad \text { L-Glutamate } & 4 \cdot 5 \pm 0 \cdot 4 & 38 \cdot 4 \pm 0 \cdot 7 \\ \text { 2-Oxoglutarate } & 2 \cdot \mathrm{I} \pm 0 \cdot \mathrm{I} & 5 \cdot 4(\text { approx. } \\ \text { Ammonium ion } & 22 \cdot 9 \pm \mathrm{I} \cdot 7 & 2 \cdot 0 \pm 0 \cdot 1 \\ K_{i} & & \\ \text { D-Glutamate/L-glutamate } & 2 \mathrm{I} \cdot \mathrm{I} \pm 9 \cdot 2 & 29 \cdot 5 \pm 4 \cdot 5 \\ \text { D-Glutamate/2-oxoglutarate } & 7 \cdot 2 \pm 0 \cdot 37 & \mathrm{Activates} \\ \text { D-Glutamate/ammonium ion } & 8 \cdot 6 \pm \mathrm{I} \cdot 4 & 5 \mathrm{I} \cdot 4 \pm 4 \cdot 5\end{array}$

* Co-operative substrate. 
Table 3. Effect of $\mathrm{D}$-glutamate contained in the assay medium on the rate of the $G D H_{\mathrm{NADP}}$ amination reaction

\begin{tabular}{|c|c|c|c|}
\hline \multirow{3}{*}{$\begin{array}{l}\text { 2-Oxoglutarate } \\
\text { concn } \\
\text { (mM) }\end{array}$} & \multicolumn{3}{|c|}{$\begin{array}{l}\text { Rate of change in } E_{340} \\
\text { (absorbance units/min/unit vol. extract) }\end{array}$} \\
\hline & \multicolumn{3}{|c|}{ D-Glutamate concn (mM) } \\
\hline & 0 & 7 & 15 \\
\hline I $\cdot 7$ & 0.001 & 0.054 & 0.049 \\
\hline 4.8 & 0.038 & 0.155 & 0.129 \\
\hline $9 \cdot 6$ & $0 \cdot 174$ & 0.215 & $0.19 I$ \\
\hline 16.8 & 0.282 & 0.237 & 0.216 \\
\hline
\end{tabular}

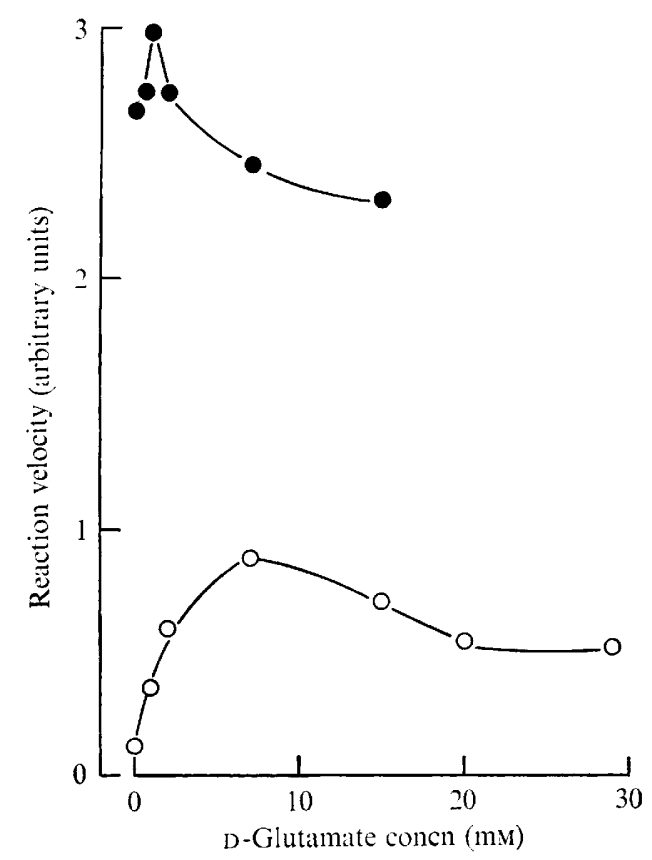

Fig. 4. Effect of various concentrations of D-glutamate on $\mathrm{GDH}_{\mathrm{NADP}}$ activity in the amination reaction of two 2-oxoglutarate concentrations: $O, 2.4 \mathrm{~mm}$; and $\odot, 24 \mathrm{~mm}$.

carbon and nitrogen sources present in the medium. There is a medium-dependence,' but only because of the influence that the medium has over the activity of the GDH enzymes.

Growth rate inhibition was reversed by addition of L-glutamate, but hardly affected by L-glutamine (Table I).

\section{Effect of D-glutamate on the activity of $G D H$}

In order to establish the mechanism as well as the degree of inhibition, activities were determined in separate experiments in which the different substrates (2-oxoglutarate, ammonium ion and L-glutamate) were varied at a number of analogue (D-glutamate) concentrations. The results are presented graphically in the single form $[\mathrm{S}] / v \times[\mathrm{S}]$, the plots being regression lines calculated from the experimental data. The data have been examined 


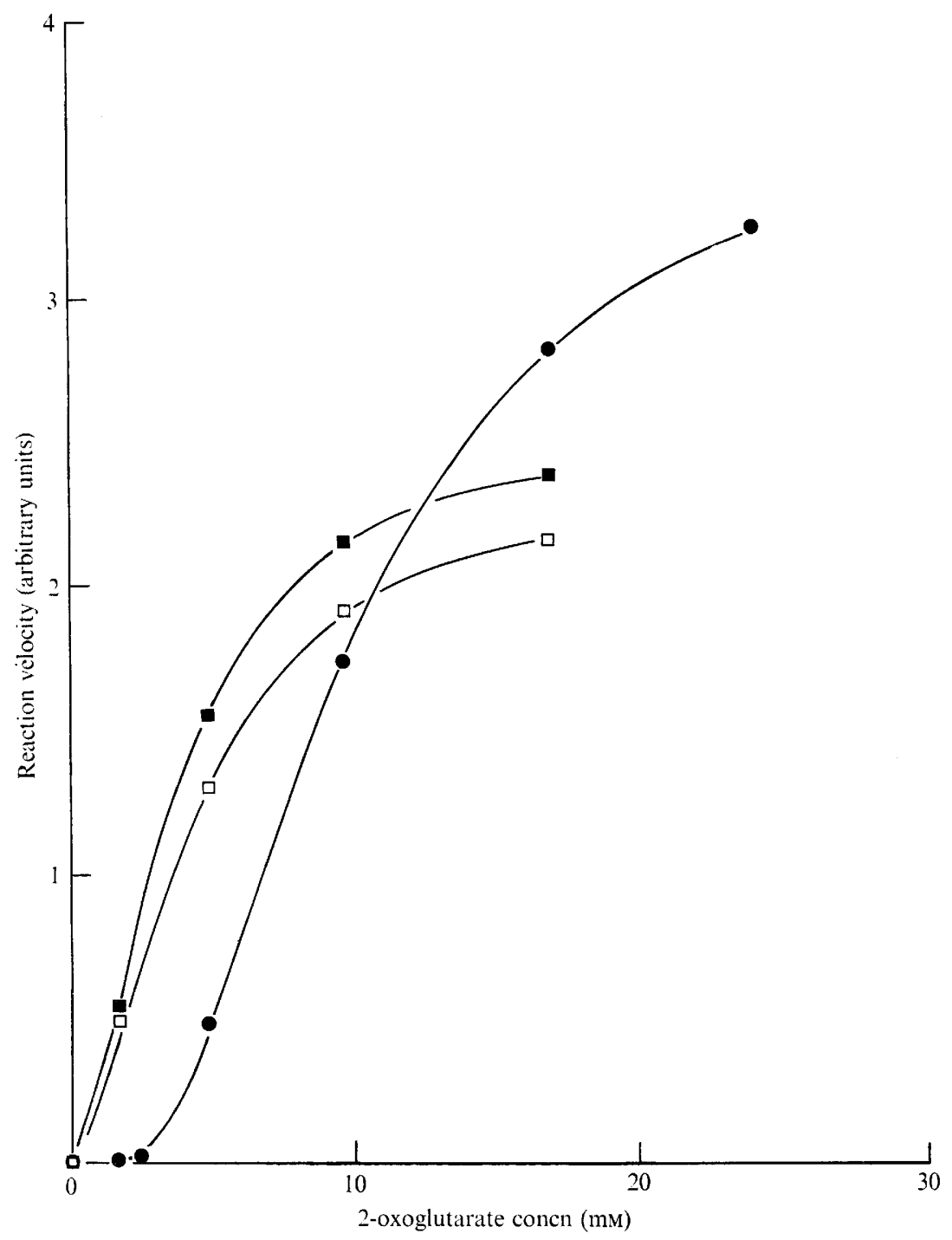

Fig. 5. Effect of various concentrations of 2-oxoglutarate on $\mathrm{GDH}_{\mathrm{NADP}}$ activity in the absence of D-glutamate (๑), and in the presence of either $7 \mathrm{~mm}(\boldsymbol{\square})$ or $15 \mathrm{~mm}(\square)$ D-glutamate.

by a number of graphical procedures (Webb, I963) to confirm the conclusions drawn from the illustrated plots.

D-Glutamate inhibits $\mathrm{GDH}_{\text {YAD }}$ activity against each of the substrates (Fig. 2). The inhibitions observed with $\mathrm{GDH}_{\mathrm{NADP}}$ are illustrated in Fig. 3. The inhibitions are mixed in all cases, although those between D-glutamate and L-glutamate are more nearly noncompetitive. The kinetic constants calculated from these data are summarized in Table 2; the values quoted are only approximate since the exact nature of the inhibitions is not known.

Inhibition of 2-oxoglutarate amination by $\mathrm{GDH}_{\mathrm{NADP}}$ was only observed at the highest concentrations of D-glutamate employed. At low concentrations D-glutamate increased the reaction velocity (Table 3 ; Fig. 4). Furthermore, direct plots of reaction velocity against 
Table 4. Effect of D-glutamate contained in the culture medium on the specific activities of Coprinus GDH enzymes

The indicated liquid media were inoculated with oidia of the wild-type monokaryotic strain $\mathrm{BC} 9 / 6,6$ and incubated in shake culture for 3 days.

Specific activity

( $\mu \mathrm{mol}$ coenzyme oxidized $/ \mathrm{min} / \mathrm{mg}$ protein)

Medium

25 mM-Acetate +25 mM-urea

25 mM-Acetate + 25 mM-urea + 5 mM-D-glutamate

$100 \mathrm{~mm}$-Glucose $+75 \mathrm{~mm}$-ammonium tartrate

$100 \mathrm{~mm}-$ Glucose $+75 \mathrm{~mm}$-ammonium tartrate + $5 \mathrm{mM}$-D-glutamate

$\begin{array}{cc}\mathrm{GDH}_{\mathrm{NAD}} & \mathrm{GDH}_{\text {NADP }} \\ 2.768 & 0.048 \\ \mathbf{I} \cdot 836 & 0.354 \\ 0.249 & 0.280 \\ 0.403 & 0.496\end{array}$

2-oxoglutarate concentration were markedly sigmoidal, approaching Michaelis-Menten kinetics only on the addition of D-glutamate (Fig. 5).

\section{Effect of D-glutamate on the specific activity of $G D H$}

The experiments reported so far have investigated the effect of D-glutamate on the activity of preformed GDH enzymes. Arkin \& Grossowicz (1970) indicated that D-glutamate derepressed $\mathrm{GDH}_{\mathrm{NADP}}$ synthesis in Neurospora. The same also seems to be true for Coprinus (Table 4) since the specific activity of $\mathrm{GDH}_{\mathrm{NADP}}$ in mycelia of strain $\mathrm{BC} / 6,6$ grown in shake culture was increased by the inclusion of D-glutamate in the medium. The derepression was particularly clear where the medium (acetate + urea) was one which itself normally repressed $\mathrm{GDH}_{\mathrm{NADP}}$. There appeared to be little or no effect on the level of $\mathrm{GDH}_{\mathrm{NAD}}$. Some changes in activity were detected, but on such a small scale that their significance is doubtful.

\section{DISCUSSION}

D-Glutamate was a potent inhibitor of mycelial growth. The fact that the degree of inhibition depended on the activity and identity of the GDH enzyme present in the mycelium encouraged the view that the two enzymes differed in their sensitivity to D-glutamate inhibition. To a considerable extent this interpretation was supported by the in vitro studies, which showed that in the deamination reaction $\mathrm{GDH}_{\mathrm{NADP}}$ had a lower affinity for D-glutamate than did $\mathrm{GDH}_{\mathrm{NAD}}$, whereas in the amination reaction $\mathrm{GDH}_{\mathrm{NAD}}$ was inhibited while $\mathrm{GDH}_{\text {NADP }}$ was activated.

In specifying features like these, the experiments have satisfied the initial aims of the project. Culture conditions for the attempted selection of resistant mutants can be devised and there is possibly scope for the use of D-glutamate as an unnatural component of morphogenesis. These experiments have also revealed some interesting contrasts with Neurospora as well as some further characters of Coprinus GDH.

The activity of $\mathrm{GDH}_{\mathrm{NADP}}$ in Neurospora was inhibited in both reaction directions by D-glutamate, with competitive inhibition between D-glutamate and 2-oxoglutarate (Arkin \& Grossowicz, 1970). This is in contrast to the activation observed under the same reaction conditions in Coprinus. This difference between the D-glutamate effects on GDH $_{\text {NADP }}$ activity in the two fungi should be compared with the apparent similarity of the effects on synthesis: in both organisms D-glutamate is an effective derepressor of $\mathrm{GDH}_{\mathrm{NADP}}$ synthesis.

These experiments have also revealed another facet of $\mathrm{GDH}_{\mathrm{NADP}}$ regulation in Coprinus. Synthesis of both GDH enzymes is subject to metabolite regulation which can be imitated 
in culture (Fawole \& Casselton, I972), and synthesis of $\mathrm{GDH}_{\mathrm{NADP}}$ is regulated intracellularly in concert with morphogenetic changes (Stewart \& Moore, 1974). We have demonstrated that 2-oxoglutarate is a co-operative substrate for Coprinus $\mathrm{GDH}_{\text {NADP }}$ while D-glutamate acts as an allosteric activator. These are two of the features described for ' $\mathrm{K}$-system' enzymes (Monod, Wyman \& Changeux, 1965) and suggest that $\mathrm{GDH}_{\mathrm{NADP}}$ in vivo may be subject to control at the level of the enzyme activity as well as at the level of transcription. Further study of these aspects of $\mathrm{GDH}_{\mathrm{NADP}}$ regulation in relation to morphogenesis should be rewarding.

The valuable advice and assistance of Dr G. R. Stewart is gratefully acknowledged; so too is the financial support provided to $\mathrm{A}$. Al -G. by the Ministry of Higher Education and Scientific Research of the Government of Iraq.

\section{REFERENCES}

ARKIN, H. \& Grossowicz, N. (1970). Inhibition by D-glutamate of growth and glutamate dehydrogenase activity of Neurospora crassa. Journal of General Microbiology 6r, 255-26r.

DenNen, D. W. \& Niederpruem, D. J. (1965). Control of glutamate dehydrogenase in the Basidiomycete Schizophyllum commune. Life Sciences 4, 93-98.

Fawole, M. O. \& CASselton, P. J. (1972). Observations on the regulation of glutamate dehydrogenase activity in Coprinus lagopus. Journal of Experimental Botany 23, 530-55I.

FrIEDEN, C. (1963). Glutamate dehydrogenase. IV. Studies on enzyme inactivation and coenzyme binding. Journal of Biological Chemistry 238, I46-I 54 .

Lowry, O. H., Rosebrough, N. J., Farr, A. L. \& Randall, R. J. (I95I). Protein measurement with the Folin phenol reagent. Journal of Biological Chemistry I93, 265-275.

Monod, J., Wyman, J. \& Changeux, J. P. (I965). On the nature of allosteric transition. A plausible model. Journal of Molecular Biology, 12, 88-1 18.

MOORE, D. (I968). The effect of 2-deoxy-D-glucose on the growth and respiration of Coprinus lagopus. Journal of General Microbiology 52, 433-439.

MOORE, D. \& SteWART, G. R. (1972). Effects of 2-deoxy-D-glucose, D-glucosamine, and L-sorbose on the growth of Coprinus lagopus hyphae. Journal of General Microbiology 7r, 333-342.

Olson, J. A. \& ANFinsen, C. B. (1953). Kinetic and equilibrium studies on crystalline L-glutamic acid dehydrogenase. Journal of Biological Chemistry 202, 84I-856.

ROBERTS, E. (1953). Further studies of inhibition of bacterial glutamic decarboxylase. Journal of Biological Chemistry 202, 359-367.

SANWAL, B. D. \& LATA, M. (1962). Concurrent regulation of glutamic acid dehydrogenases of Neurospora. Archives of Biochemistry and Biophysics 97, 582-588.

STEWART, G. R. \& MoORE, D. (1974). The activities of glutamate dehydrogenases during mycelial growth and sporophore development in Coprinus lagopus (sensu Lewis). Journal of General Microbiology 83, 73-8r.

STINE, G. J. (1968). Enzyme activities during the asexual cycle of Neurospora crassa. II. NAD- and NADPdependent glutamic dehydrogenases and nicotinamide adenine dinucleotidase. Journal of Cell Biology $37,8 I-88$.

Tuveson, R. W., West, D. J. \& Barratt, R. W. (1967). Glutamic acid dehydrogenases in quiescent and germinating conidia of Neurospora crassa. Journal of General Microbiology 48, 235-248.

WebB, J. L. (1963). Enzyme and Metabolic Inhibitors, vol. I. New York: Academic Press. 